This item is the archived peer-reviewed author-version of:

Taxonomizing performance measurement systems' failures

\title{
Reference:
}

Van Camp Jelle, Braet Johan.- Taxonomizing performance measurement systems' failures

International journal of productivity and performance management - ISSN 1741-0401 - 65:5(2016), p. 672-693

Full text (Publisher's DOI): https://doi.org/10.1108/JJPPM-03-2015-0054

To cite this reference: http://hdl.handle.net/10067/1330250151162165141 


\title{
Taxonomizing performance measurement systems' failures
}

\begin{abstract}
After more than 30 years of research, literature on performance measurement systems (PMS) is characterized by diversity and fragmentation. Due to the multidisciplinarity of stakeholders and researchers involved the basis of literature is expanding, but not converging. More specific, failures of PMS are dispersedly discussed in the abundance of literature written.
\end{abstract}

Over 250 articles related to PMS have been analyzed in order to shortlist failures of PMS. Two criteria have been used: (1) explicitly referenced being a failure, or (2) mentioned as being essential for a successful PMS. Next steps were clustering, cross-checking with academics and professionals, and re-allocation to appropriate levels.

This paper identifies 36 failures and proposes an easy taxonomy for further referencing by attribution to three levels: metric, framework and management. Failures range from uncertainties in data gathering, lack of knowledge and dealing with complexity, towards the allocation of necessary resources.

Limitations are attributed to the abundance of research published on PMS. Consequently, incorporated papers are a subset representing the current state of the research domain. Furthermore, the completeness of the list can be discussed as well as the level of generalization of the proposed taxonomy.

Both academics and professionals can benefit from this study as it creates an awareness of the risks involved when constructing, implementing and managing a PMS. Therefore, this original research ought to be seen as a catalyst for a learning curve, as it puts the research of PMS in a different perspective. 


\section{On performance measurement and management}

Since the early 80 s increased attention has been addressed to map the performance of an organization by means of performance metrics, as they may aid in achieving the company's goals more efficiently and effectively (Cedergren et al., 2010; Chiesa and Masella, 1996; Garengo et al., 2005). Especially, at a company and macro level, practitioners strive to get accurate insights on how the organization or cluster of organizations is performing. On a daily basis, incubator managers, EU commissionaires, project leaders and CEOs are confronted with the dynamic and complex interplay between input and output, cause and result. All want to know how efficiently resources are being transformed into desirable products (or services) with added value for the customer. This heterogeneous mix of shareholders presents a first challenge of the research domain: different perspectives and a broad application.

Researchers from various backgrounds attempt to analyze the topic of performance measurement; leading to a multidisciplinary research domain touching upon multiple fields: e.g. cost accounting; operations, supply chain and risk management; management information systems; change management; psychology and sociology. Consequently, a variety of performance measurement and management systems has seen the light in order to assess different operational aspects of running a business. Many authors reconstructed the evolution of the multidimensional research domain and can be reread there: Neely et al. (1995), Nudurupati et al. (2011), Bititci et al. (2012). One can clearly see that a broad approach necessitates a common language, in order to facilitate long desired cooperation and counter confusion of tongues. Cooperation to push the research domain forward, has never been so relevant. 
Hence, in line with the purpose of this conceptual paper, it is essential to start with definitions to get a clear image of some key concepts. Lebas and Euske (2011) highlight the fact that performance is largely defined by its context. In essence, performance relates to the effectiveness and efficiency of a process. Meaningful definitions of performance within a business context, take the specificity of the company into account. Performance then refers to a potential for value creation and is a result of many (sub)processes, which can all be researched and analyzed separately or combined. (Lebas and Euske, 2011; Pollanen, 2005).

Performance measurement could be defined as "the process of quantifying the efficiency and effectiveness of (past) action" (Neely et al., 2002, 1995), adding and emphasizing the process of quantification to the previous definition. The concept of a performance measurement system is not as straightforward as it looks. Franco-Santos et al. (2007) discuss 17 diverse definitions of business performance measurement systems, acknowledging that 'the lack of agreement on a definition creates confusion and clearly limits the potential for generalizability and comparability of research'. Concluding their paper, they state prerequisites, such as features, roles and processes of business performance measurement systems to lead to a definition. Literature defines performance measurement systems as: 'a balanced and dynamic system that is able to support the decision-making process by gathering, analyzing and expanding information'. (Bititci et al., 2000; Garengo and Bititci, 2007; Neely et al., 1995, 2002).

Turban et al. (2011) frame performance measurement as an essential part of performance management, stating that 'business performance management is an integrated set of processes, methodologies, metrics and [technological] applications (...) by extending the monitoring, measuring and comparing of performance indicators by introducing (...) 
management and feedback'. Other authors, e.g. Bourne and Neely (2000), add, with reason, the connotation that this could be used both top-down as bottom-up: respectively to enforce corporate strategy for the long run and to use performance measures to facilitate the management of organization's performance through daily practices.

When looking at the purpose of a (business) performance measurement system (PMS), multiple reasons for implementation can be raised. Six reasons were synthetized from various authors, concluding that PMSs map the current business and support management in taking informed decisions (Bititci et al., 1997, 2002; Franco-Santos et al., 2007; Turban et al., 2011):

i plan, monitor, evaluate, control and communicate financial and operational activities;

ii inform (and aid) the decision-maker;

iii maximize the effectiveness and drive improvement by optimizing profitability;

iv achieve alignment with organizational goals, objectives and strategy;

v reward and discipline staff and management;

vi forecast near and future outcomes.

Despite thirty years of research and thousands of research papers and articles, many questions and uncertainties concerning performance measurement in business still remain unanswered (Micheli and Manzoni, 2010; Rubinstein, 2004). This leads to three conclusions: (1) the amount of research done shows the general interest in the subject and (2) the amount of questions left unanswered gives an indication of the complexity of performance measurement as a research topic or (3) points to a number of more fundamental problems inhibiting an effective progress of the field. 
Furthermore, a difference is noted between the theoretical promises that a PMS should deliver and the actual performance of the system. Literature warns us for implementing an inappropriate system or using a system inappropriately, because (1) it is detrimental for the measurements, (2) it results in an ineffective performance measurement system and (3) it might be harmful for the whole company as incorrect decisions become supported and scarce resources get squandered by erroneous allocation to incentives that fail to deliver (Bird et al., 2005; Chiesa et al., 1996; Kuczmarski, 2001; Micheli and Manzoni, 2010). Well-constructed supportive business performance measurement frameworks followed by rigorous decision making could meet in this problem (Meyer, 2011).

\section{Performance measurement systems' failures constitute a research gap}

When researching global literature, articles can be found ranging from general management systems to very specific measurement frameworks. Moreover, many academics are researching the topic from a variety of backgrounds. Researchers from accounting, economics, information systems, human resource management, marketing, operations management, psychology and sociology are independently exploring the field without much collaboration (Neely, 2011; Bitici et al., 2012). Dominantly, academic research was occupied with financial and purely R\&D based indicators (OECD, 2005), leading to a skewed view on innovation- and business measurement in general. Hence, the existing diversity leads to a lack of fundamental basis where everyone agrees upon.

Literature acknowledges the abundance of publications related to PMSs and strives for convergence in order to advance further. This overload can be illustrated by referring to the work of Neely (1999), who shows that in three years, between 1994 and 1996 over 3.600 articles were published on performance measurement, heralding the "performance 
measurement revolution" (Neely, 2005). Van Camp and Braet (2013) indicate attention has increased with near to 100.000 items published between 1994 and 2011. Nudurupati et al. (2011) agree on Holloway's (2001) notion that previous and contemporary literature is widely diverse and fragmented over particular individual models and frameworks for performance measurement.

On the other hand, strikingly few overview papers can be found focusing on lessons learned from actual applications. Successful business cases or failure analyses are a scarce find in literature. Key authors produce material discussing possible guidelines for measurement systems, rather than trying to build preliminary guidelines for deriving new metrics (Micheli and Mari, 2014). In general, literature lacks substance when trying to build a case on failed systems, nor does literature incorporate descriptions or analyses of practical problems encountered. Only a limited amount of studies on performance measurement systems mention less than five failures or merely discuss singular and independent cases. For further examples and references, the authors refer to Kellen (2003); Kennerley and Neely (2002); Kuczmarski (2001); Nudurupati (2011). Failure analysis, though a method stemming from a manufacturing perspective, could hold interesting insights for further research. To the authors' knowledge, no attempt has been made to give a comprehensive overview of performance measurement systems' failures.

Additionally, the modus operandi for this paper also taps into a method of sustainable development: ongoing evaluation, which is grounded in constructive dialogues, critical examination (of successes and failures) and dissemination of knowledge (Svensson et al, 2009). This interactive approach, including dynamic feedback loops is deemed to be very interesting, especially in a more practical context. 


\section{Purpose and scope}

In addition to recent work of Bititci and al. (2012), which focusses on the broad theme of evolution and development of performance measurement systems, this paper gives an overview of common failures leading to a non-functioning PMS, i.e., not aiding the decision maker in a substantial way, therefore not justifying the resources spent for the conception and implementation of the PMS. Subsequently, this overview of failures presents a list of caveats bewaring both academics and professionals. The failure, originating from literature or practice, can be translated into a caveat, warning other professionals. Furthermore, this approach supports a novel learning curve for the research domain. More precise, the general purpose and applications of this study is manifold and should (initially) be seen within the light of PMS research. The major contributions of this paper are ennumerated:

i obtaining a structured overview of common failures reported in (recent) literature;

ii adding clear definitions, offering a better understanding of PMSs;

iii getting insights on how PMSs' failures can be categorized;

iv facilitating communication for future research

$\mathrm{v} \quad$ acting as a guideline for reviewing old or devising new frameworks, thereby paving the way for standardization;

vi presenting a checklist of failures in order for professionals to get an overview of caveats when introducing a PMS.

As the research domain is widely diverse, the authors did not want to restrict the scope too much disabling the discovery a vast amount of possible failures. The starting point of this analysis was determined by looking for specific contributions in literature yielding information on successes and failures of performance measurement systems, as will be 
discussed in the methodology section. Documents discussing operations research, management accounting, but also practices from SMEs and product development were analyzed.

\section{Methodology}

Based on an extensive literature review (comparable to the approach of Bititci et al. (2012), who also apply a systematic literature review supplemented with individually selected works based on citations and key references to other papers), empirical insights and brainstorming sessions with both academics and professionals, the authors have built a taxonomy to classify pitfalls dealing with measurement systems. This second phase in the methodology can be further broken down into four dynamic steps with continuous feedback and updating: (1) listing of failures, (2) categorizing, (3) clustering and (4) validating.

More in detail, to come to this paper, over 250 documents have been screened, consisting of articles in various scientific journals, conference proceedings, (text)books, $\mathrm{PhD}$ theses, dedicated magazine articles and generic documents. Eventually, a selection had to be made to constitute the proposals in this paper. Literature was incorporated dealing with (1) the construction of a performance measurement framework, to discover the do's and don'ts, and (2) documents tackling encountered difficulties, both from a theoretical as from an implementation perspective. Pitfalls were shortlisted based on two criteria. First: the obstacle was explicitly referenced as being a failure related to PMSs and hence should be avoided. Second: the caveat was already mentioned as being essential (needed and necessary) for the success of a good working PMS. The number of identified failures grew sigmoidal to 40 . Throughout the course of the research, the authors identified four main classes of failures, i.e., failures at (1) metric level, (2) framework level, (3) implementation level and (4) failures due 
to the inherent complex nature of business, innovation and uncertainty in the development process, underpinning the three previous levels. In a second phase, in cooperation with academic experts, the four levels were reduced to three by allocating the problems under the header of complexity, to the appropriate other levels of metrics, frameworks and management (previously named implementation). Herewith, the authors converged independently towards the classification devised by Pettigrew et al. (1989) and used by Bourne et al. (2002).

\section{$<$ Insert table 1. Taxonomy of encountered pitfalls when dealing with measurement systems >}

In a third step a further reduction of failures was made, retaining 36 caveats, allocated to the three levels of failures as presented in table 1. This number was mainly the result of a clustering process by means of combining same types of failure under a more abstract denominator. For the purpose of comprehensibility, this trade-off between being precise and being encompassing was the challenge of this paper. If a similar failure was encountered both at metric and framework level, it was allocated to the lowest level - metric in this case. The argumentation for this decision lies in the fact that, often, when a failure can be solved at a lower level, it (partially) solves the problem at a higher level. For example: clear, well defined measurements contribute to easier, more straightforward processing in the model and in management. In a final step, the results have been cross-checked with academics and professionals to validate the proposed taxonomy and to get feedback on the relatability, completeness and user-friendliness of this list.

\section{Lessons learnt funnel into a taxonomy of failures}

The underlying research has identified plural factors that could lead to the failure of the performance measurement system. These failures can be attributed to three levels. The first 
level contains difficulties with the metrics: failures allocated to the measurements, parameters and key performance indicators. Secondly, failures allocated to the framework and model, i.e., the processing of the measures (the performance measurement systems minus the metrics themselves). And finally, failures at a third level which encompasses the support given and decisions taken by management: failures attributed to the implementation or operability of the PMS.

The three levels contain thirteen, nine and fourteen failures respectively, totaling to thirty-six caveats for the practitioner. Tables 2,3 and 4 propose a taxonomy for the encountered performance measurement systems' failures. This paper, and incorporated tables, should be seen as the synthesis of a larger study, merely presenting take away messages. Elaborating on every failure individually leads to a document too large to publish in a journal. Therefore, a brief description has been added to clarify the failures. Furthermore, the table offers exemplary references that can be used as a starting point for further study. In a final column, implications are hinted upon by the authors, based on experience and interactions with a practitioners. Note, that these implications are an indication and are subjected to further research.

While the main contribution of the paper is presented in table 2 to 4 , a written expansion on the failures can be found in following paragraphs. This brief elaboration indicates the complex and interconnected nature of the problems a practitioner is facing. For no reason, it is claimed to be an encompassing list, nor does this narrative overview touch upon every single intricacy. This list proposes a framework for further analysis. 


\section{Metric Level >}

\section{Failures at metric level}

Thirteen failures were identified at metric level. These failures can mainly be attributed to questions on data gathering: what, how, how much and when to measure. Throughout literature, many authors consent that the basis of confusion often originates from a lack of clear, unique and transparent definition of the metric, i.e. measurement or KPI (M1). Many authors therefore strive for convergence and the need of a common language to promote clarity, precision and uniformity (Franco-Santos, 2007; Geisler, 2002; Neely, 1998; Pawar and Driva, 1999; Richard et al., 2009; Schneiderman, 1999).

It is commonly seen that, especially in small and medium enterprises, difficulties arise when needing to construct a PMS, due to the lack of knowledge and/or motivation. Companies consequently demonstrate copy-paste behavior and look to other, often bigger, companies to resort to (M2). Such a list of metrics is easily transposed, without further changes being made. As been discussed by Kennerly and Neely (2002), these approaches often fail.

Furthermore, the selected metrics could be chosen for reasons of practicality. Companies quickly turn to subjective approaches due to various limitations: lack of available and accessible data points (M3), difficulties translating intangibles (M7), uncertainty (M13) or plain resource constraints, i.e. time, people, money (Ma). As a consequence a biased and incomplete set, with easy measurements, will limit the effectiveness of the PMS (M8), eventually leading to a failing PMS. 
Many authors have tried to tackle the research question of what a balanced set of metrics is. Ultimately, as the concept of performance is multi-faceted and encompasses multiple dimensions, the PMS should give information on all. Metrics both internal (operational efficiencies, financial parameters...) to the company as external (market size and growth, customer preferences and technological trends) should be integrated (Krishnan and Ulrich, 2001; Franco-Santos, 2007; Neely, 2011). Various aspects should be integrated (think widely acclaimed Balanced Scorecard), therefore making the actual selection of a complete set of metrics a cumbersome endeavor. When discussing a set of metrics, attention needs to be drawn to the aspect of complementarity, as to not overload the framework with dozens of metrics. Metrics should be chosen carefully without too big of an overlap (Arundel and O'Brien, 2009; Pawar and Driva, 1999). A continuous validation of the active metrics could warrant a dedicated and actual set of metrics fit to map the performance of business (see also F5).

\section{< Insert table 3. Proposed taxonomy for performance measurement systems' failures - Framework Level >}

\section{Failures at framework level}

When analyzing topic-specific published research, the audience obtains a rather broad image of the concept of a performance measurement framework. This is mainly due to the fact that no elucidating definition can be found in literature. More than some vague common characteristics, i.e. "balanced", "giving an overview", "multidimensional", "comprehensive”, “cross-functional”, “function of determinants' (Neely et al., 2011), or cryptical definitions, i.e. "a conceptual foundation of a PMS" (Marchand and Raymond, 2008), or "an approach for building a BPM" (Kellen, 2003) cannot be found. Looking up the definition of a framework in a dictionary does not grant satisfying results either. Oxford University Press (2012) defines a 
framework as "a basic structure underlying a system", where a system is defined as "a set of things working together as a part of a mechanism or interconnected network".

Meredith (1993) talks about 'explanatory conceptual frameworks', "a collection of two or more interrelated propositions which explain an event, provide understanding or suggest testable hypotheses", putting them on par with 'pre-theories'. In performance measurement literature, a framework often refers to a set of techniques, or (mathematical) models and methods to analyze registered measurements. Ideally, a framework encompasses a manual or guideline, albeit conceptual, on how to construct and manage the performance measurement system in practice.

Moreover, a framework defines the scope (F1) and sets out the dimensions that should be included in the study (F2). Difficulties incorporating different dimensions, e.g. accounting, HRM, marketing, operations management, product design, eventually lead to inertia and failure of the PMS. This heterogeneity also shines through in the vast amount of available performance measurement frameworks (F3), that all try to capture pieces of the performance puzzle.

The problem with this abundance of possible frameworks is that different approaches lead to different estimates of performance (Jacobs, 2001; Smith and Goddard, 2002). This bias in recommendations and results is not acceptable and leads to mixed opinions and a lack of consensus (Neely et al., 2002, 2000). The overload of frameworks demonstrates the reluctance towards (easy) acceptance of PMSs.

Generic and obsolete frameworks contain limited knowledge and are detrimental for the acceptance and success of the PMS. Both knowledge and deep understanding of the 
developed system could aid in countering these failures (F4). Additionally, the framework itself can aid the user in various ways in selecting and processing up-to-date measurements by introducing feedback and learning curves (F5) and take the intrinsic difficulties surrounding dynamic complexities of innovative industries into account (F9).

\section{< Insert table 4. Proposed taxonomy for performance measurement systems' failures - Management Level >}

\section{Failures at management level}

Management plays a crucial supporting role in the process of building an operational and successful PMS, beginning from the decision to construct one, preparing the in-house culture, to freeing up enough resources for its implementation and daily usage. From literature, the authors have deducted 14 possible failures that could occur at management level.

The lack of general support from management is seen as one of the crucial factors for failing PMSs (Ma1). Literature brings forward five reasons why managers fail to commit. First, there is the senior management inertia or obstinacy regarding holding on to conservative practices (Kennerly and Neely, 2002). Smith and Goddard (2002) phrase this even more strongly as 'the lack of ambition for improvement' by (a) continuing doing business without a PMS in place or (b) clinging on to a conservative (i.e. old) set of metrics. Secondly, researchers have noticed a lack of interest and motivation to consistently commit to a PMS; the willingness to maintain the PMS fades over time (Kostoff, 1998). A third reason refers to the lack of available time for managers to occupy with non-operational activities (Garengo et al., 2005). Contrary, the PMS should act as an aid for the manager to make operational decisions more efficient and effective. The fourth reason suggests a lack of managerial commitment due to a 
perceived lack of benefits (Bourne et al., 2000, 2002). When this is true the PMS definitely needs revision in order to exhibit its added value to the company. Contrary, the same authors worn for being too eager - a fifth reason - as putting too much effort in the success rate of the PMS might frighten employees and other stakeholders.

The lack of managerial support may trigger some additional problems, such as not providing the necessary resources (Ma6, Ma7, Ma8) (Jacoby, 2012), lack of involvement in the followup (Ma9), or lack in reactive/ proactive actions (Ma11), eventually leading to the general downfall of the PMS as a whole.

\section{Discussion}

To initiate the discussion, four points of interest are highlighted. The first remark relates to the abundance of existing literature and the resulting diverse (and fragmented) references incorporated in this paper. A variety of research disciplines contributed to the general knowledge of PMSs, leading to works of reference from many perspectives. This paper has tried to link them by a fil rouge, being the failures that the frameworks encounter. A minor quantity of papers focusing on SME's and governmental programs were included, but the authors argue that lessons from these specific sectors may be extrapolated to support general conclusions. Moreover, as indicated in the overview paper of Bititci et al. (2012), SME's are essential for (regional) economic growth and their dynamic context should exhibit dynamic (and interesting to study) PMSs as well. The bibliography incorporated can act as a starting point for further research, as many extra studies exist in the research domain. By selecting a diverse set of literature - considered to be equal to a random selection process - and by choosing for an appropriate level of abstraction in the analysis, the authors have built a representative overview concerning failures of PMSs. 
A second note refers to the completeness of the list of failures presented. 36 caveats are proposed, challenging other researchers to devise new caveats, based on failures that cannot be integrated in the proposed framework under the existing denominations. A trade-off had to be made between adding an entire new headers to the list or possibly rephrasing the new failure, in order to fall in line with the proposed nomenclature.

Third, the researchers had to allocate different failures to a general taxonomy. The authors remark that the clustering of legio failures is not an exact science and some subjectivity is present. By entering the dialogue with multiple experts, the subjectivity was reduced to a minimum. However, it can be seen that many failures are interconnected and entwined with one another.

Finally, the strength of this research will show in the future, if people adapt to the nomenclature proposed by consistently using the intended terms. By using a transparent and unambiguous vocabulary, miscommunications will be reduced to a minimum and comparison and benchmarking will be facilitated.

\section{Conclusion}

Thirty years of research characterized by slow but steady growth indicates the global interest in the topic, but also exemplifies the underlying complexity. Reviewing the existing literature on performance measurement systems showed that the research domain is characterized by ambiguity in definitions and a general lack of convergence, mainly due to the large diversity in interdisciplinary studies. When digging deeper into literature, other difficulties arise within the research domain. Only a conservative learning curve is present with limited cooperation 
and interaction between research domains. Clear and unambiguous exchange of know-how and best practices could boost further research and applications.

The added value of this paper lies in the presentation of an overview of the identified failures appointed to the different levels of a PMS: (1) metric level, (2) framework level and (3) management level. Tables 2 to 4 synthesize existing literature and proposes a transparent and user-friendly taxonomy. Applications are manifold, but mainly ought to be seen as a catalyst for learning curves within the domain. Academics, but mainly practitioners could benefit from these frameworks.

\section{Further research}

This paper grounds a framework of 36 failures, based on available literature. It is clear to see that every failure could produce a research question on its own. What causes these failures? Is one failure more severe than another? Three paths for further research are suggested.

An obvious first challenge lies into the research on how to cope with the presented failures and which solutions could be offered. Some available research attempts to meet in these difficulties dispersedly, but remains scarce.

Main research challenges are the following, cfr. failures mentioned in M1 throughout Ma14.

- Is it feasible to construct a widely accepted lexicon for metrics?

- Can we derive generally applicable metrics or could we learn which ones are industry specific?

- How to measure intangibles better, e.g. level of innovation, quality of a product, customers' satisfaction, morale, leadership? 
- How do we take uncertainty into account and how is this reflected in the models and frameworks?

- How to combine metrics from different perspectives, with different units?

- How to integrate feedback loops and learning curves in the used frameworks?

- What are the alternatives to (arbitrary chosen) weights for different parameters?

- How to align a PMS with mid- and long-term strategies?

Secondly, further review studies could be made analyzing existing frameworks, based on this taxonomy. Which failures, as presented in $\mathrm{M}$ (etrics) and $\mathrm{F}$ (rameworks) are inherent to commonly used PMSs? Furthermore, when looking at best practices or real life cases, which failures, discussed in Ma(nagement) are encountered? On the other hand, how do good performing PMSs score against these common pitfalls? These follow up studies could shed more light on the ambiguity and evolution of the research domain, unraveling present complexity, as a common framework for research has been presented.

A third venue for research deals with the correlation between the failures of performance measurement systems as discussed in this paper. As referred to, throughout the paper, many failures are not isolated problems but are entwined with one another. Further study might look deeper into these relations by constructing for example a correlation matrix - or even a(n) (expected or assumed) causality matrix - or influence diagram, highlighting single or mutual relations between the failures of performance measurement systems. These deeper insights might enable resolving rigidly embedded failures by focusing on the underlying difficulties. 


\section{References}

Andrew, J., Haanaes, K., Michael, D., Sirkin, H. and Taylor, A. (2008), "A BCG Senior Management Survey", Measuring Innovation 2008: Squandered Opportunities, The Boston Consulting Group.

Arundel, A. and O'Brien, K. (2009), "Innovation Metrics For Australia", in Kelly, P., Pettifer, K. and Pennifold, C. (eds.), Consolidated Report Innovation Metrics Framework project, Australian Innovation Research Centre (AIRC), Canberra, Australia, p.132.

Baglieri, E., Chiesa, V., Grando, A., and Manzini, R. (2001), "Evaluating Intangible Assets: The Measurement of R\&D Performance", Research paper, SDA Bocconi School of Management, Milan, 2001.

Bierbusse, P. and Seisfeld, T. (1997), "Measures that matter", Journal of Strategic Performance Measurement, Vol. 1, No. 2, p. 6-11.

Bird, S. M., Cox, D., Farewell, V., Goldstein, H., Holt, T., and Smith, P. (2005), "Performance indicators: good, bad, and ugly", Journal of the Royal Statistics Society: Series A, Vol. 168, No. 1, p. 1-27.

Bititci, U. S., Carrie, A. S., and McDevitt, L. (1997), "Integrated performance measurement systems: a development guide", International Journal of Operations \& Production Management, Vol. 17, No. 5, p. 522-534.

Bititci, U., Carrie, A. S., and Turner, T. (2002), "Integrated Performance Measurement Systems: Structure and Dynamics", In Neely, A. (Ed.), Business Performance Measurement: Theory and Practice, Cambridge university Press, Cambridge.

Bititci, U., Garengo, P., Dörfler, V. and Nudurupati, S. (2012), "Performance Measurement: Challenges for Tomorrow", International Journal of Management Reviews, Vol. 14, p. 305327.

Bititci, U. S., Carrie, A. S., and McDevitt, L. (1997), "Integrated performance measurement systems: a development guide", International Journal of Operations \& Production Management, Vol. 17, No. 5, p. 522-534.

Bititci, U. S., Turner, T., and Begemann, C. (2000), "Dynamics of performance measurement systems", International Journal of Operations \& Production Management, Vol. 20, No. 6, p. 692-704.

Bourne, M., Mills, J., Wilcox, M., Neely, A., and Platts, K. (2000), "Designing, implementing and updating performance measurement systems", International Journal of Operations \& Production Management, Vol. 20, No. 7, p. 754-771.

Bourne, M., Neely, A., Platts, K., and Mills, J. (2002), "The success and failure of performance measurement initiatives: Perceptions of participating managers", International Journal of Operations \& Production Management, Vol. 22, No. 11, p. 1288-1310. 
Brouthers, K.D., (1998), "Driving Blind : Strategic Decision- making in Small Companies", Long Range Planning, Vol. 31, No. 1, p. 9.

Bruns, W. (1998), "Profit as performance measure: powerful concept, insufficient measure", in Performance Measurement: Theory and Practice, 14-17 July, Cambridge.

Cedergren, S., Wall, A., and Norström, C. (2010), "Evaluation of performance in a product development context", Business Horizons, Vol. 53, No. 4, p. 359-369.

Chen, Y.M., Goan, M. and Cheng, P. (2010), "Uncertainty and Risk Analysis in Information System Projects Development”, Journal of Uncertain Systems, Vol. 4, No. 1, pp.34-46.

Chiesa, V. and Masella, C. (1996), "Searching for an effective measure of R\&D performance", Management Decision, Vol. 34, No. 7, p. 49-57.

Cooper, R. G. (1985), "Selecting winning new product projects", Journal of Product Innovation Management, Vol. 2, p. 34-44.

Cooper, R. and Kaplan, R. S. (1988), "Measure Costs Right: Make the Right Decisions", Harvard Business Review, October, p 96-103.

Cross, K. and Lynch, R. (1988), "The SMART way to define and sustain success", National Productivity Review, Vol. 8, No. 1, p. 23-33.

Davenport, T. H. (2006), "Competing on analytics", Harvard business review, January, p. 9.

Davenport, T. H. and Harris, J. G. (2005), “Automated decision making comes of age”, MIT Sloan Management Review, 2005, p. 82-90.

Eccles, R.G., (1991), “The performance measurement manifesto", Harvard business review, February, p.131-137.

EFQM (1988), “The EFQM excellence model”, available at: http://www.efqm.org/en/tabid/132/default.aspx (last accessed 26 June 2012).

Epstein, M. and Westbrook, R. (2001), "Linking actions to profits in strategic decision making", MIT Sloan Management Review, Spring, p. 39-49.

Fitzgerald, L., Johnston, R., Brignall, T., Silvestro, R., and Voss, C. (1991), Performance Measurement in Service Business, CIMA Publishing, London.

Ford, J. D. and Schellenberg, D. a. (1982), "Conceptual Issues of Linkage in the Assessment of Organizational Performance", The Academy of Management Review, Vol. 7, No. 1, p. 4958.

Franco-Santos, M., Kennerley, M., Micheli, P., Martinez, V., Mason, S., Marr, B., Gray, D., and Neely, A. (2007), "Towards a Definition of Business Performance Measurement System", International Journal of Operations \& Production Management, Vol. 27, No. 8, p.784-801. 
Garengo, P., Biazzo, S., and Bititci, U. S. (2005), "Performance measurement systems in SMEs: A review for a research agenda", International Journal of Management Reviews, Vol. 7, No. 1, p. 25-47.

Garengo, P. and Bititci, U. (2007), "Towards a contingency approach to performance measurement: an empirical study in Scottish SMEs", International Journal of Operations \& Production Management, Vol. 27, No. 8, p. 802-825.

Gass, G. L. and Prince, C. (1993), "Family of Measures: A Tool for Continuous Improvement", in Christopher, W. F., Thor, C. G. (Eds.), Handbook for Productivity Measurement \& Improvement, Productivity Press, p. 4-8.1 - 4-8.12.

Geisler, E. (2000), The metrics of science and technology. Quorum Books, Westport, CT.

Geisler, E. (2002), "The metrics of technology evaluation: where we stand and where we should go from here", International Journal of Technology Management, Vol. 24, No. 4, p. 341-374.

Griffin, A. and Page, A. L. (1993), “An Interim Report on Measuring Product Development Success and Failure", Journal of Product Innovation Management, Vol. 10, No. 4, p. 291308.

Griffin, A. and Page, A.L. (1996), "PDMA Succes Measurement Project: Recommended Measures for Product Development Succes and Failure", Journal of Product Innovation Management, Vol. 13, pp.478-496.

Hauser, J. and Katz, G. (1998), "Metrics: you are what you measure!", European Management Journal, Vol. 16, No. 5, p. 517-528.

Heidenberger, K. and Stummer, C. (1999), "Research and development project selection and resource allocation: a review of quantitative modelling approaches", International Journal of Management Reviews, June, pp.197-224.

Holloway, J. (2001), "Investigating the impact of performance measurement", International Journal of Business Performance Measurement, Vol. 3, No. 2-4, p. 167-180.

Hope, J., (2011), "Budgeting to the adaptive organization", in A. Neely, (ed), Performance Measurement - Theory and Practice. pp. 163-178.

Hubbard, D. W. (2007), How to Measure Anything: Finding the Value of Intangibles in Business. John Wiley \& Sons, Hoboken, NJ.

Hudson Smith, M. and Smith, D. (2007), "Implementing strategically aligned performance measurement in small firms", International Journal of Production Economics, Vol. 106, No. 2, p. 393-408.

Islei, G., Lockett, G., Barry, C., Gisbourne, S. and Stratford, M. (1991), "Modeling Strategic Decision Making and Performance Measurements at ICI Pharmaceuticals", Interfaces, Vol. 21, No. 6, p.4-22. 
Jacobs, R. (2001), "Alternative methods to examine hospital efficiency: data envelopment analysis and stochastic frontier analysis", Health care management science, Vol. 4, No. 2, p.103-115.

Jacoby, A. (2012), Performance in the Front-end of Innovation: linking strategy to requirement, $\mathrm{PhD}$ thesis, University of Antwerp, Belgium.

Jansen-Vullers, M.H. and Netjes, M. (2006), "Business Process Simulation - A Tool Survey", paper presented at the Seventh Workshop and Tutorial on Practical Use of Coloured Petri Nets and the CPN Tools, October 24-26, 2006, Aarhus, Denmark, p.20.

Johne, F.A. and Snelson, P.A. (2000), "Success Factors in Product Innovation: A selective review of the literature", in Millson, M.R. \& Wilemon, D. (eds), Performance Measurement \& Control Systems for Implementing Strategy. Prentice Hall, New Jersey, pp. 307-322.

Kaplan, R. and Norton, D. (2000), The Strategy-focused Organization: How Balanced Scorecard Companies Thrive in the New Business Environment, Harvard Business Review Press, Boston, MA.

Kaplan, R. S. and Norton, D. P. (1992), "The balanced scorecard - measures that drive performance”, Harvard Business Review, Vol. 70, No. 1, p. 71-9.

Keegan, D., Eiler, R., and Jones, C. (1989), “Are Your Performance Measures Obsolete?”, Management Accounting, June, p. 38-43.

Kellen, V. (2003), "Business Performance Measurement: At the Crossroads of Strategy, Decision-Making, Learning and Information Visualization", working paper, DePaul University, Chicago, Feb 2003.

Kennerley, M. and Neely, A. (2002), "A framework of the factors affecting the evolution of performance measurement systems", International Journal of Operations \& Production Management, Vol. 2, No. 11, p. 1222-1245.

Kerssens-van Drongelen, I., Nixon, B., and Pearson, A. (2000), "Performance measurement in industrial R\&D”, International Journal of Management Reviews, Vol. 2, No. 2, p. 111-143.

Kostoff, R. N. (1998), "Metrics For Planning and Evaluating Science and Technology Metrics should be embedded in a more comprehensive evaluation process", $R \& D$ Enterpise - Asia Pacific, Vol. 1, No. 2-3, p. 30-33.

Kostoff, R. N. (2002), "Science and Technology Transition Metrics", Generic document, March 2002, p.1-15.

Kostoff, R. N. and Geisler, E. (2007), "The unintended consequences of metrics in technology evaluation", Journal of Informetrics, Vol. 1, No. 2, p. 103-114.

Krishnan, V. and Ulrich, K. T. (2001), "Product Development Decisions: A Review of the Literature", Management Science, Vol. 47, No. 1, p. 1-21. 
Kuczmarski, T. (2001), "Five Fatal Flaws of Innovation Metrics", Marketing Management, Vol. 10, No. 1, p. 34-39.

Lazzarotti, V., Manzini, R., and Mari, L. (2011), "A model for R\&D performance measurement. International Journal of Production Economics", Vol. 134, No. 1, p. 212-223.

Lebas, M. and Euske, K. (2011), "Conceptual and operational delineation of performance", in Neely, A. (Ed.), Performance Measurement - Theory and Practice, Cambridge University Press, Cambridge, p. 125-142.

Liao, S.-h. (2005), "Technology management methodologies and applications", Technovation, Vol. 25, No. 4, p. 381-393.

Lynch, R. and Cross, K. (1995), Measure Up: Yardsticks for Continuous Improvement, Blackwell Business, Hoboken, NJ.

Malone, T.W., Laubacher, R. and Dellarocas, C. (2009), "Harnessing Crowds : Mapping the Genome of Collective Intelligence", working Paper, MIT Center for Collective Intelligence, Cambridge, MA, Feb. 2009.

Marchand, M. and Raymond, L. (2008), "Researching performance measurement systems: An information systems perspective", International Journal of Operations \& Production Management, Vol. 28, No. 7, p. 663-686.

Meredith, J. (1993), "Theory Building through Conceptual Methods", International Journal of Operations \& Production Management, Vol. 13, No. 5, p. 3-11.

Meyer, M. (2011), "Finding Performance: New discipline in management", in Neely, A. (Ed.), Performance Measurement - Theory and Practice, Cambridge University Press, Cambridge, p. 113-124.

Meyer, M. and Gupta, V. (1994), The Performance Paradox. In Staw, B. and Cummings, L. (Eds.), Research in Organizational Behavior, JAI Press, Greenwich, p. 309-369.

Micheli, P. and Manzoni, J.-F. (2010), "Strategic Performance Measurement: Benefits, Limitations and Paradoxes", Long Range Planning, Vol. 43, No. 4, p. 465-476.

Micheli, P. and Mari, L. (2014), "The theory and practice of performance measurement. Management Accounting Research”, Vol. 25, No. 2, p.147-156.

Mizuno, S. and Akao, Y. (1994), "QFD, the Customer-Driven Approach to Quality Planning and Deployment", Asian Productivity Organization, Tokyo, Japan.

Neely, A. (1998), Measuring Business Performance, Economist Books, London.

Neely, A. (1999), “The performance measurement revolution: why now and what next?", International Journal of Operations \& Production Management, Vol. 19, No. 2, p. 205-228. 
Neely, A. (2005), "The evolution of performance measurement research: Developments in the last decade and a research agenda for the next", International Journal of Operations \& Production Management, Vol. 25, No. 12, p. 1264-1277.

Neely, A. (2011), Business Performance Measurement: Unifying Theory and Integrating Practice. Cambridge University Press, Cambridge.

Neely, A., Adams, C., and Kennerley, M. (2002), The Performance Prism: The Scorecard for Measuring and Managing Business Success. Financial Times/ Prentice Hall, New Jersey.

Neely, A., Gregory, M., and Platts, K. (1995), "Performance measurement system design: A literature review and research agenda", International Journal of Operations \& Production Management, Vol. 15, No. 4, p. 80-116.

Neely, A., Mills, J., Gregory, M., Richards, H., Platts, K., and Bourne, M. (1996), Getting the Measure of Your Business, Manufacturing Engineering Group, Cambridge.

Neely, A., Mills, J., Platts, K., Richards, H., Gregory, M., Bourne, M., and Kennerley, M. (2000), "Performance measurement system design: developing and testing a process-based approach”, International Journal of Operations \& Production Management, Vol. 20, No. 10, P. 1119-1145.

Nudurupati, S., Bititci, U., Kumar, V., and Chan, F. (2011), "State of the art literature review on performance measurement", Computers \& Industrial Engineering, Vol. 60, No. 2, p. 279290.

Nunamaker, J.F., Brigs, R.O., Mittleman, D.D., Vogel and D.R., Balthazard, P.A., (1997), "Lessons from a Dozen Years of Research: A Discussion of Lab and Field Findings", Journal of Management Information Systems, Vol. 13, No. 3, p.163-207.

OECD (2005), "Oslo Manual: Guidelines for collecting and interpreting innovation data", available at: http://www.oecd.org/document/33/0,3746,en_2649_34273_35595607_1_1_1_1,00.html (last accessed 26 June 2012).

Oxford University Press (2012), "Oxford Dictionaries: Framework", available at: http://oxforddictionaries.com/definition/english/framework?q=framework (last accessed Oct. 29, 2012].

Pawar, K. S. and Driva, H. (1999), "Performance measurement for product design and development in a manufacturing environment", International Journal of Production Economics, Vol. 60-61, p. 61-68.

Pettigrew, A., Whipp, R. and Rosenfield, R. (1989), "Competitiveness and the management of strategic change processes", in Franics, A. and Tharakan, P. (Eds.), The competitiveness of European industry: Country Policies and Company Strategies, Routledge, London, p. 210.

Pollanen, R. M. (2005), "Performance measurement in municipalities: Empirical evidence in Canadian context", International Journal of Public Sector Management, Vol. 18, No. 1, p. 424. 
Purdy, J. (2005), "Decisions, Delusions \& Debacles. The University of Georgia Research Magazine", available at: http://researchmagazine.uga.edu/summer2005/printgambling.htm (last accessed: 12 March 2012).

Rangone, A. (1996), "An analytical hierarchy process framework for comparing the overall performance of manufacturing departments", International Journal of Operations \& Production Management, Vol. 16, No. 8, p.104-119.

Read, N. and Batson, J. (1999), "Business Dynamics: Spreadsheet Modelling Best Practice", IBM document, April, p. 1-102.

Richard, P.J., Devinney, T.M., Yip, G.S. and Johnson G. (2009), "Measuring Organizational Performance: Towards Methodological Best Practice", Journal of Management, Vol. 35, No. 3, p.718-804.

Roth, G. L. and Senge, P. M. (1996), "From theory to practice: research territory, processes and structure at an organizational learning centre", Journal of organizational change management, Vol. 9, No. 1, p. 92-106.

Rubinstein, A. (2004), "50 years of engineering and technology management", IEEE Transactions and Engineering Management, Vol. 51, No. 4, p. 407-408.

Savage, S. (2009), The Flaw of Averages. John Wiley \& Sons, Hoboken, NJ.

Schneiderman, A. M. (1999), "Why balanced scorecards fail", Journal of Strategic Performance Measurement, January 1999, p. 6-11.

Scozzi, B., Garavelli, C. and Crowston, K. (2005), "Methods for modeling and supporting innovation processes in SMEs", European Journal of Innovation Management, Vol. 8, No. 1, p.120-137.

Simons, R. (2000), Performance Measurement \& Control Systems for Implementing Strategy, Prentice Hall, New Jersey.

Smith, P. C. and Goddard, M. (2002), "Performance management and operational research: a marriage made in heaven?", Journal of the Operational Research Society, Vol. 53, No. 3, p. 247-255.

Spitzer, D. R. (2007), Transforming Performance Measurement: Rethinking How You and Your Organization Use Measurement. AMACOM, New York, NY.

Stern, J. and Stewart, B. (2013), "Company history: 1980s", available at: http://www.sternstewart.com/?content=history\&p=1980s (last accessed Aug. 1, 2013).

Suwignjo, P., Bititci, U., and A.S Carrie (2000), "Quantitative models for performance measurement system", International Journal of Production Economics, Vol. 64, No. 1-3, p. 231-241. 
Svensson, L., Brulin, G., Jansson, S. and Sjoberg, K. (2009), Learning Through Ongoing Evaluation. Studentlitteratur AB, Sweden.

Turban, E., Sharda, R., and Delen, D. (2011), Decision Support and Business Intelligence Systems. Pearson, New Jersey.

Van Camp, J. and Braet, J. (2013), "Proposing a taxonomy for performance measurement systems' failures", working paper 2013-004, University of Antwerpen, Antwerpen, March 2013.

Verworn, D.B. and Herstatt, P.C. (1999), "Approaches to the "Fuzzy Front End" of Innovation”, working Paper (2), TU Harburg, Sept. 1999.

Veugelers, R. (2006), "Developments in EU Statistics on Science, Technology and Innovation", in Science, Technology and Innovation Indicators in a Changing World: Responding to Policy Needs, proceedings of the Blue Sky Indicator Conference, Sept. 25 - 27, 2006, Ottawa, Canada, OECD Publishing, pp. 33-46.

Ziliak, S. T. and McCloskey, D. N. (2008), The Cult of Statistical Significance: How the Standard Error Costs Us Jobs, Justice, and Lives, University of Michigan Press, Michigan. 
Table 2. Taxonomy of encountered pitfalls when dealing with measurement systems

\begin{tabular}{|ll|}
\hline Bourne et al. (2002); Pettigrew et al. (1989) & Proposed taxonomy \\
\hline Measurement Content & Metric Level \\
\hline Development Process & Framework Level \\
\hline Organizational Context & Management Level \\
\hline
\end{tabular}


Table 2. Proposed taxonomy for performance measurement systems' failures - Metric Level

\begin{tabular}{|c|c|c|c|}
\hline Code & Failure at metric level & Description & Implications \\
\hline M1 & $\begin{array}{l}\text { Lack of clear, unique and transparent } \\
\text { definition } \\
\text { (Cedergren et al., 2010; Geisler, 2002; Hauser } \\
\text { and Katz, 1998; Hubbard, 2007; Lazzarotti et } \\
\text { al., 2011; Marchand and Raymond, 2008; } \\
\text { Micheli and Manzoni, 2010; Neely, 1998; } \\
\text { Neely, 1999; Pawar and Driva, 1999; } \\
\text { Schneiderman, 1999; Turban et al., 2011) }\end{array}$ & $\begin{array}{l}\text { Due to (1) the large diversity of roles of the } \\
\text { PMSs themselves and (2) the need to } \\
\text { incorporate multiple dimensions, it is } \\
\text { essential having well documented and } \\
\text { unambiguous operational definitions. Authors } \\
\text { urge for clearly stating the item (what?), the } \\
\text { unit (how?) and the value (why?). }\end{array}$ & $\begin{array}{l}\text { Standardized definitions or lexicon } \\
\text { understood and adopted by key players } \\
\text { within the organization. By extent an } \\
\text { internationally accepted lexicon of keywords. }\end{array}$ \\
\hline M2 & $\begin{array}{l}\text { Transposed from other companies } \\
\text { (Holloway, 2001; Kennerley and Neely, 2002; } \\
\text { Pawar and Driva, 1999) }\end{array}$ & $\begin{array}{l}\text { Due to a lack of knowledge, motivation } \\
\text { and/or financial resources, companies } \\
\text { demonstrate a copy-paste-behavior from } \\
\text { (often) larger companies. However, off the } \\
\text { shelf metrics and systems pose insufficient } \\
\text { flexibility. }\end{array}$ & $\begin{array}{l}\text { A step by step manual for constructing a } \\
\text { personalized set of metrics. Could be } \\
\text { initialized by (external) best practices, but } \\
\text { should be tailored to own needs. }\end{array}$ \\
\hline M3 & $\begin{array}{l}\text { Selected on accessibility and availability } \\
\text { (Bird et al., 2005; Gass and Prince, 1993; } \\
\text { Geisler, 2000; Hauser and Katz, 1998; Kostoff, } \\
\text { 2002; Smith and Goddard, 2002) }\end{array}$ & $\begin{array}{l}\text { The true total cost of a PMS should not be } \\
\text { underestimated. Major contributors are } \\
\text { construction and maintenance of the system, } \\
\text { gathering and structuring of information, time } \\
\text { cost of all individuals involved. Therefore, } \\
\text { companies resort to what is fast, easy and } \\
\text { cost-efficient to measure. Consequently, } \\
\text { biases are present, undermining the system } \\
\text { and leading to incorrect decisions. }\end{array}$ & $\begin{array}{l}\text { Transparent cost-benefit analysis could aic } \\
\text { the decision maker in seeing the added value } \\
\text { of a well-constructed PMS. }\end{array}$ \\
\hline M4 & $\begin{array}{l}\text { Unbalanced amount } \\
\text { (Bierbusse and Seisfeld, 1997; Kaplan and } \\
\text { Norton, 2000; Kennerley and Neely, 2002; } \\
\text { Kuczmarski, 2001; Meyer, 2011; Meyer and } \\
\text { Gupta, 1994; Nudurupati et al., 2011; Pawar } \\
\text { and Driva, 1999; Spitzer, 2007; Suwignjo at } \\
\text { al., 2000; Turban et al., 2011) }\end{array}$ & $\begin{array}{l}\text { Obliquity or oversimplification is obtained if } \\
\text { respectively too many or too little indicators } \\
\text { are monitored. The former is promoted by an } \\
\text { inability to discard metrics (lack of dynamic } \\
\text { metrics) or a lack of focus. The latter might be } \\
\text { a result of failure M3 or a limited focus on } \\
\text { financial output metrics. }\end{array}$ & $\begin{array}{l}\text { Improvements in IT (registration, analysis } \\
\text { reporting) increase the manageable amount } \\
\text { of metrics. Populate subcategories evenly } \\
\text { with a limited set of metrics. }\end{array}$ \\
\hline
\end{tabular}




\begin{tabular}{|c|c|c|c|}
\hline M5 & $\begin{array}{l}\text { Dominant focus on financial metrics } \\
\text { (Bruns, 1998; Kuczmarski, 2001; Meyer, 2011; } \\
\text { Neely, 2011; Neely et al., 2002) }\end{array}$ & $\begin{array}{l}\text { Historically, the dominant focus is on financial } \\
\text { metrics. However, authors suggest that it is } \\
\text { more interesting to measure what is } \\
\text { necessary (input and process) in order to } \\
\text { profit. Financial output metrics complicate } \\
\text { the analysis by being lagging indicators, } \\
\text { hinting on what has been set into stone. } \\
\text { Furthermore, it is difficult to allocate financial } \\
\text { output to input, negating possible synergies. }\end{array}$ & $\begin{array}{l}\text { A balanced amount of financial and non- } \\
\text { financial metrics, ranging from input over } \\
\text { process to output. Although many metrics } \\
\text { could be transformed into a monetary impact } \\
\text { on the organization and not per se merely } \\
\text { traditional financial metrics. } \\
\text { Complementing financial data with non- } \\
\text { financial data paints a broader and more } \\
\text { accurate picture of the performance of an } \\
\text { organization. }\end{array}$ \\
\hline M6 & $\begin{array}{l}\text { Unbalanced ratio between qualitative and } \\
\text { quantitative metrics } \\
\text { (Baglieri et al., 2001; Holloway, 2001; Liao, } \\
\text { 2005; OECD, 2005; Pawar and Driva, 1999) }\end{array}$ & $\begin{array}{l}\text { Difficulties in obtaining figures or a lack of } \\
\text { advanced calculations make one resort to an } \\
\text { over-usage of qualitative metrics representing } \\
\text { a more subjective approach, leading to less } \\
\text { robust outcomes. Over-emphasizing } \\
\text { quantitative metrics erroneously became } \\
\text { synonym with 'over-monetization', i.e. trying } \\
\text { to measure everything with financial metrics } \\
\text { (M5). }\end{array}$ & $\begin{array}{l}\text { Integrating both types of data urges for } \\
\text { different approaches in methodology. A } \\
\text { systemic approach needs to be united with } \\
\text { expert advice and human behavior, drawing } \\
\text { upon a correctly used methodology. } \\
\text { Qualitative metrics could be further broken } \\
\text { down into smaller building blocks that could } \\
\text { be measured at different levels and by other } \\
\text { means. }\end{array}$ \\
\hline M7 & $\begin{array}{l}\text { Difficulties measuring intangibles } \\
\text { (Baglieri et al., 2001; Geisler, 2002; Hubbard, } \\
\text { 2007; Kellen, 2003; Neely, 2011; OECD, 2005) }\end{array}$ & $\begin{array}{l}\text { Most companies struggle measuring non- } \\
\text { physical attributes robustly. Their approach is } \\
\text { (1) to query (expert) users, (2) to measure } \\
\text { expenditure and R\&D resources and (3) to } \\
\text { zoom in on patent statistics. An interesting } \\
\text { interplay is being created between } \\
\text { intangibles, qualitative and quantitative } \\
\text { approximations. }\end{array}$ & $\begin{array}{l}\text { Transparent definitions are initial step, paving } \\
\text { the way for further breakdown into (more } \\
\text { tangible) proxies. } \\
\text { If it is important, it has an impact that can be } \\
\text { measured. If it does not have an impact, is it } \\
\text { important? }\end{array}$ \\
\hline M8 & $\begin{array}{l}\text { Incomplete set } \\
\text { (Arundel and O'Brien, 2009; Baglieri et al., } \\
\text { 2001; Franco-Santos et al., 2007; Geisler, } \\
\text { 2000; Hudson Smith and Smith, 2007; Kaplan } \\
\text { and Norton, 1992; Kennerley and Neely, } \\
\text { 2002; Krishnan and Ulrich, 2001; Kuczmarski, }\end{array}$ & $\begin{array}{l}\text { The multiple dimensions of the PMS } \\
\text { aggravate the metric selection process, as a } \\
\text { sufficient degree of coverage is endeavored: } \\
\text { internal and external metrics; input, process } \\
\text { and output metrics. Different authors } \\
\text { propose a different framework, e.g., balanced }\end{array}$ & $\begin{array}{l}\text { Complementarity is key. Carefully choose } \\
\text { metrics within a clearly identified scope for a } \\
\text { clearly identified goal. }\end{array}$ \\
\hline
\end{tabular}




\begin{tabular}{|c|c|c|c|}
\hline & $\begin{array}{l}\text { 2001; Lazzarotti et al, 2011; Neely, 2011; } \\
\text { Pawar and Driva, 1999; Veugelers, 2006) }\end{array}$ & $\begin{array}{l}\text { score-card measures } 4 \text { perspectives: } \\
\text { financials, ( } 2 \text { ) internal business processes, }(3) \\
\text { learning and growth, (4) customers. }\end{array}$ & \\
\hline M9 & $\begin{array}{l}\text { Danger of metrics becoming targets } \\
\text { (Hauser and Katz, 1998; Hubbard, 2007; } \\
\text { Kostoff, 1998; Kostoff and Geisler, 2007; } \\
\text { Smith and Goddard, 2002; Spitzer, 2007) }\end{array}$ & $\begin{array}{l}\text { "Measurements done to prove will rarely } \\
\text { improve." Measurement fixation will obstruct } \\
\text { clear vision of the goal and may stimulate } \\
\text { counter-desirable results. This failure } \\
\text { intensifies when coupled with an } \\
\text { inappropriate reward system. }\end{array}$ & $\begin{array}{l}\text { Taking care when selecting metrics and } \\
\text { implementing a dynamic reward system. The } \\
\text { need arises to regularly re-assess the } \\
\text { feasibility of the metric in an evolving } \\
\text { context. Transparent communication of the } \\
\text { place and order of the metric in the larger } \\
\text { PMS. }\end{array}$ \\
\hline M10 & $\begin{array}{l}\text { Lack of robust metrics } \\
\text { (Arundel and O'Brien, 2009; Bird et al., 2005; } \\
\text { Gass and Prince, 1993; Geisler, 2000; } \\
\text { Hubbard, 2007; Lazzarotti et al., 2011; Neely, } \\
\text { 1998; Smith and Goddard, 2002; Spitzer, } \\
\text { 2007) }\end{array}$ & $\begin{array}{l}\text { The value of the metric should be based on } \\
\text { measurable values and not easy to be } \\
\text { manipulated or gamed by the "provider } \\
\text { staff". Combining robustness, specificity and } \\
\text { sensitivity is a difficult task. }\end{array}$ & $\begin{array}{l}\text { The combination of different parameters } \\
\text { embedded into a functional framework can } \\
\text { build up to a robust and sensitive metric that } \\
\text { measures the target precisely. }\end{array}$ \\
\hline M11 & $\begin{array}{l}\text { Lack of objective metrics } \\
\text { (Cooper, 1985; Hubbard, 2007; Lazzarotti et } \\
\text { al., 2011; Neely, 1998; Purdy, 2005; Savage, } \\
\text { 2009; Spitzer, 2007; Turban et al., 2011) }\end{array}$ & $\begin{array}{l}\text { One resorts to subjective metrics due to } \\
\text { various limitations: lack of available data } \\
\text { (M3), difficulties translating intangibles (M7), } \\
\text { uncertainty (M12) and limited resources } \\
\text { (time, people and money). Different authors } \\
\text { warn for shortcomings of arbitrary scoring } \\
\text { models. }\end{array}$ & $\begin{array}{l}\text { Limit subjective questionnaires and pay } \\
\text { attention to its design. Only use estimation, } \\
\text { when other resorts fail. }\end{array}$ \\
\hline M12 & $\begin{array}{l}\text { Uncertainty at the beginning of a project } \\
\text { (Baglieri et al., 2001; Cooper, 1985; Lazzarotti } \\
\text { et al., 2011) }\end{array}$ & $\begin{array}{l}\text { Initial uncertainty obstructs the analysis of } \\
\text { metrics encountered further in the } \\
\text { production process, e.g., during the stage of } \\
\text { idea generation or idea selection, little is } \\
\text { known about the actual production and } \\
\text { distribution costs or sales. }\end{array}$ & $\begin{array}{l}\text { Benchmark data or expert estimations taking } \\
\text { all failures mentioned above into account. } \\
\text { Predictions based on Monte Carlo } \\
\text { simulations, risk analyses and/or decision tree } \\
\text { analyses. }\end{array}$ \\
\hline M13 & $\begin{array}{l}\text { Misuse of deterministic metrics } \\
\text { (Bird et al., 2005; Cedergren et al., 2010; }\end{array}$ & $\begin{array}{l}\text { "It is better to be roughly right than precisely } \\
\text { wrong." Often accuracy, precision and }\end{array}$ & $\begin{array}{l}\text { It is desirable to initiate a probabilistic } \\
\text { approach taking into account variation and }\end{array}$ \\
\hline
\end{tabular}


Hauser and Katz, 1998; Hubbard, 2007; deterministic values are treated as synonyms. uncertainty, to introduce confidence intervals

Lazzarotti et al., 2011; Savage, 2009)

One should take care of the "flaw of

averages" by discarding too much

information and only keep point estimates, as

they propose a comfortable but false sense

of precision. or to offer outcomes, in order to give an expression to the existing uncertainty. 
Table 3. Proposed taxonomy for performance measurement systems' failures - Framework Level

\begin{tabular}{|c|c|c|c|}
\hline Code & Failure at framework level & Description & Implications \\
\hline F1 & $\begin{array}{l}\text { Lack of articulated scope } \\
\text { (Baglieri et al., 2001; Davenport and Harris, } \\
\text { 2005; Garengo et al., 2005; OECD, 2005; } \\
\text { Simons, 2000; Turban et al., 2011) }\end{array}$ & $\begin{array}{l}\text { Imprecise scope leads to inefficient } \\
\text { framework and models as they represent a } \\
\text { subset of reality always not all internal and } \\
\text { external effects are integrated. }\end{array}$ & $\begin{array}{l}\text { Dimensions could encompass: (1) one project, } \\
\text { portfolio or company, (2) certain domains and } \\
\text { fields, (3) process: input, throughput, output. }\end{array}$ \\
\hline F2 & $\begin{array}{l}\text { Difficulties incorporating different } \\
\text { dimensions } \\
\text { (Baglieri et al., 2001; Garengo et al., 2005; } \\
\text { Kellen, 2003; Liao, 2005; Neely, 2011) }\end{array}$ & $\begin{array}{l}\text { Aspects related to accounting, IT, HRM, } \\
\text { marketing, operations management, } \\
\text { psychology, sociology... all use different } \\
\text { languages and preferences obstructing } \\
\text { integration. }\end{array}$ & $\begin{array}{l}\text { Starting from an accepted lexicon, models } \\
\text { could be built including all dimensions listed } \\
\text { Cross-disciplinary research project presents } \\
\text { solutions to this multivariate problem. }\end{array}$ \\
\hline F3 & $\begin{array}{l}\text { Overload of divers frameworks } \\
\text { (Jacobs, 2001; Kellen, 2003; Neely et al., } \\
\text { 2000; Neely et al., 2000; Smith and Goddard, } \\
\text { 2002) }\end{array}$ & $\begin{array}{l}\text { Large diversity in the research domain } \\
\text { triggered legio frameworks, all with different } \\
\text { approaches, leading to different estimates of } \\
\text { 'performance'. }\end{array}$ & $\begin{array}{l}\text { A database with general information, focus, } \\
\text { strengths and weaknesses could benchmark } \\
\text { current frameworks. Secondly, are more } \\
\text { frameworks needed? }\end{array}$ \\
\hline F4 & $\begin{array}{l}\text { Lack of understanding } \\
\text { (Bititci et al., 2001; Ford and Schellenberg, } \\
\text { 1982; Garengo et al., 2005; Holloway, 2001; } \\
\text { Hubbard, 2007; Kellen, 2003; Savage, 2009; } \\
\text { Schneiderman, 1999; Smith and Goddard, } \\
\text { 2002; Suwignjo et al., 2000; Ziliak and } \\
\text { McCloskey, 2008) }\end{array}$ & $\begin{array}{l}\text { Too often, due to the complex nature of the } \\
\text { innovation process, the frameworks and } \\
\text { suggested models are being kept as black } \\
\text { boxes, with limited knowledge on correlation } \\
\text { and causality. }\end{array}$ & $\begin{array}{l}\text { Training employees in the possibilities and } \\
\text { usage of the framework. CIO could manage } \\
\text { the system and follow up on strategic } \\
\text { decisions. Transparency and justifiability is } \\
\text { key. }\end{array}$ \\
\hline F5 & $\begin{array}{l}\text { Lack of feedback and learning curve } \\
\text { (Bourne et al., 2000); Davenport, 2006; } \\
\text { Garengo et al., 2005; Kostoff, 1998; } \\
\text { Kuczmarski, 2001; Lazzarotti et al., 2011; } \\
\text { Meyer, 2011; Micheli and Manzoni, 2010; } \\
\text { Neely, 1998; Spitzer, 2007) }\end{array}$ & $\begin{array}{l}\text { Generic and obsolete frameworks contain } \\
\text { limited knowledge. It should be updated } \\
\text { regularly to follow the path of the } \\
\text { organization and support (daily) business. }\end{array}$ & $\begin{array}{l}\text { Introducing frequent feedback loops } \\
\text { guarantee metrics to be up-to-date. Regular/ } \\
\text { continuous re-assessment of the metric: do } \\
\text { they (still) measure valuable aspects of the } \\
\text { business? }\end{array}$ \\
\hline F6 & $\begin{array}{l}\text { Calculus with incompatible scales } \\
\text { (Hubbard, 2007; Turban et al., 2011) }\end{array}$ & $\begin{array}{l}\text { Nominal, ordinal, interval and ratio scales } \\
\text { propose different calculations and } \\
\text { (descriptive) statistics. In practice many } \\
\text { mistake are made. }\end{array}$ & $\begin{array}{l}\text { Basic course in statistics and a genera } \\
\text { awareness of the problem should be able to } \\
\text { root out this problem. }\end{array}$ \\
\hline
\end{tabular}




\section{F7 Bias due to weights \\ (Cooper , 1985; Hubbard, 2007; Lazzarotti et al., 2011)}

\section{F8 Lack of data}

(Cooper, 1985; Geisler, 2000; Kuczmarski, 2001; OECD, 2005; Pawar and Driva, 1999)

\section{F9 Dynamic complexity}

(Baglieri et al., 2001; Bititci et al., 2001; Bourne et al., 2000; Cedergren et al., 2010; Garengo et al., 2005; Geisler, 2000; Geisler, 2002; Griffin and Page, 1996; Holloway, 2001; Kerssens-van Drongelen et al., 2000; Lazzarotti et al., 2011; Nudurupati et al., 2011; OECD, 2005; Roth and Senge, 1996; Smith and Goddard, 2002)
Results could be inverted by introducing Group Decision Support Systems (GDSS),

various weights in the framework. Chosen Multi Criteria Decision Analysis (MCDA), Multi arbitrarily or incorrectly incorrect decisions Actor Multi Criteria Analysis (MAMCA). could be supported.

Live data is essential for fine-tuning the Tackling underlying impediments, both at proposed model. Lack of data obstructs the metric level and at management level could conception of a tailored model. solve or circumvent this caveat.

The extent to which the relationship between Getting clear insights in the underlying

cause and resulting effects are distant in time and space, hinders straightforward analysis of input and output parameters. processes and relations is. Design of experiments or ceteris-paribus thought experiments could aid in tackling this inherent difficulty. 
Table 4. Proposed taxonomy for performance measurement systems' failures - Management Level

\begin{tabular}{|c|c|c|c|}
\hline Code & Failure at management level & Description & Implications \\
\hline Ma1 & $\begin{array}{l}\text { Lack of managerial commitment } \\
\text { (Bourne et al., 2000; Bourne et al., 2002; } \\
\text { Garengo et al., 2005; Garengo and Bititci, } \\
\text { 2007; Griffin and Page, 1996; Kellen, 2003; } \\
\text { Kennerly and Neely, 2002; Kostoff, 1998; } \\
\text { Kuczmarski, 2001; Nudurupati et al., 2011; } \\
\text { Schneiderman, 1999; Scozzi et al., 2005; } \\
\text { Smith and Goddard, 2002; Spitzer, 2007) }\end{array}$ & $\begin{array}{l}\text { Conservatism, lack of interest, time or } \\
\text { perceived benefits, or the eagerness to make } \\
\text { it work could lead to a lack of general support } \\
\text { from management. }\end{array}$ & $\begin{array}{l}\text { Additional training and motivation of the } \\
\text { people working with the PMS. Translation } \\
\text { into monetary gains and losses could trigger } \\
\text { the interest that is needed. }\end{array}$ \\
\hline Ma2 & $\begin{array}{l}\text { Lack of alignment with strategy } \\
\text { (Bourne et al., 2000; Bourne et al., 2002; } \\
\text { Eccles, 1991; Garengo et al., 2005; Kellen, } \\
\text { 2003; Neely, 1999; Schneiderman, 1999; } \\
\text { Spitzer, 2007) }\end{array}$ & $\begin{array}{l}\text { Misalignment with mid- and long term } \\
\text { defined objectives and strategy could push } \\
\text { progress in various untargeted directions. }\end{array}$ & $\begin{array}{l}\text { Explicitly stating the contribution of every } \\
\text { single metric to the strategy. }\end{array}$ \\
\hline Ma3 & $\begin{array}{l}\text { Lack of formal procedure } \\
\text { (Bird et al., 2005; Bourne et al., 2002; } \\
\text { Garengo and Bititci, 2007; Johne and Snelson, } \\
\text { 2000; Kellen, 2003; Neely et al., 2000; Pawar } \\
\text { and Driva, 1999; Schneiderman, 1999; Scozzi } \\
\text { et al., 2005) }\end{array}$ & $\begin{array}{l}\text { Absence of a minimal viable formal process } \\
\text { for implementation and oparationality } \\
\text { hinders communication and clear } \\
\text { responsibilities. Beware for a too rigid } \\
\text { procedure. }\end{array}$ & $\begin{array}{l}\text { A formal and clearly written process (timings } \\
\text { and responsible for data collection, } \\
\text { processing, review, (re)actions and learning } \\
\text { curve) aids in communicating towards all } \\
\text { stakeholders. }\end{array}$ \\
\hline Ma4 & $\begin{array}{l}\text { Insufficient frequency } \\
\text { (Bird et al., 2005); Cedergren et al., 2010; } \\
\text { Griffin and Page, 1996; Hope, 2011; Kennerley } \\
\text { and Neely, 2002; Spitzer, 2007; Suwignjo et } \\
\text { al., 2000) }\end{array}$ & $\begin{array}{l}\text { Failing to update the metric frequently (daily, } \\
\text { weekly, monthly; depending on the } \\
\text { underlying unit) an overload or lack of data } \\
\text { could make the metric useless. }\end{array}$ & $\begin{array}{l}\text { Depending on available resources, priorities } \\
\text { should be set to update metrics in order to } \\
\text { keep metrics flexible, but robust. }\end{array}$ \\
\hline Ma5 & $\begin{array}{l}\text { Lack of reward system } \\
\text { (Hauser and Katz, 1998; Smith and Goddard, } \\
\text { 2002; Turban et al., 2011) }\end{array}$ & $\begin{array}{l}\text { Undesigned and accidental effects of an } \\
\text { inappropriately conceived reward systems } \\
\text { could foster dysfunctional outcomes. }\end{array}$ & $\begin{array}{l}\text { Aligning performance goals with incentives } \\
\text { could push performance in the right direction. }\end{array}$ \\
\hline Ma6 & $\begin{array}{l}\text { Lack of financial support } \\
\text { (Bierbusse and Seisfeld, 1997; Bourne et al., } \\
\text { 2002; Garengo et al., 2005; Garengo and }\end{array}$ & $\begin{array}{l}\text { Time spendings of employees, an } \\
\text { new/additional reward system, outsourcing } \\
\text { to external consulting services, new hard- and }\end{array}$ & $\begin{array}{l}\text { Identification of the most risk contributing } \\
\text { parameters to efficiently allocate resources. } \\
\text { Clearly state the pay-off. }\end{array}$ \\
\hline
\end{tabular}




\begin{tabular}{|c|c|c|c|}
\hline & $\begin{array}{l}\text { Bititci, 2007; Hudson Smith and Smith, 2007; } \\
\text { Micheli and Manzoni, 2010; Rangone, 1996; } \\
\text { Read and Batson, 1999; Scozzi et al., 2005; } \\
\text { Turban et al., 2011) }\end{array}$ & $\begin{array}{l}\text { software... is cost intense. A lack of resources } \\
\text { might lead to incomplete and ineffective } \\
\text { PMSs. }\end{array}$ & \\
\hline Ma7 & $\begin{array}{l}\text { Lack of human capital } \\
\text { (Davenport and Harris, 2005; Kellen, 2003; } \\
\text { Kennerley and Neely, 2002; Neely et al., 2000; } \\
\text { Pawar and Driva, 1999; Scozzi et al., 2005; } \\
\text { Turban et al., 2011) }\end{array}$ & $\begin{array}{l}\text { By absence of skills and capabilities, both at } \\
\text { managerial as operational level, } \\
\text { misinterpretation of the framework, the } \\
\text { model, the data and information is } \\
\text { detrimental for the PMS. }\end{array}$ & $\begin{array}{l}\text { An adapted PMS, tailored to the needs of the } \\
\text { company will limit the amount of black boxes } \\
\text { Further training could aid in the } \\
\text { understanding of the implemented system. }\end{array}$ \\
\hline Ma8 & $\begin{array}{l}\text { Lack of supporting IT } \\
\text { (Bierbusse and Seisfeld, 1997; Bourne et al., } \\
\text { 2000; Bourne et al., 2002; Cooper, 1985; } \\
\text { Jansen-Vullers and Netjes, 2006; Kellen, 2003; } \\
\text { Kuczmarski, 2001; Marchand and Raymond, } \\
\text { 2008; Nudurupati et al., 2011; Pawar and } \\
\text { Driva, 1999; Schneiderman, 1999; Suwignjo et } \\
\text { al., 2000) }\end{array}$ & $\begin{array}{l}\text { Inadequate IT support could hinder } \\
\text { implementation and ease of usage of the } \\
\text { PMS. Difficulties: integration with existing IT, } \\
\text { elevated costs, data quality assurance, black } \\
\text { boxes... }\end{array}$ & $\begin{array}{l}\text { Suitable hard- and software: a centra } \\
\text { database, a user friendly interface, skilled } \\
\text { support... facilitates frequent usage. The } \\
\text { investments should be rationalized over time. }\end{array}$ \\
\hline Ma9 & $\begin{array}{l}\text { Lack of user involvement } \\
\text { (Bird et al., 2005; Heidenberger and Stummer, } \\
\text { 1999; Holloway, 2001; Islei et al., 1991; } \\
\text { Kaplan and Norton, 2000; Kellen, 2003; } \\
\text { Suwignjo et al., 2000) }\end{array}$ & $\begin{array}{l}\text { Not consulting the users when developing, } \\
\text { introducing and deploying the PMS could lead } \\
\text { to overcomplicated models, black boxes, a } \\
\text { lack of identification and commitment. }\end{array}$ & $\begin{array}{l}\text { Users on all levels: management, employees, } \\
\text { IT-support, should be involved early on in the } \\
\text { process of integrating a PMS. }\end{array}$ \\
\hline Ma10 & $\begin{array}{l}\text { Cultural obstacles } \\
\text { (Bourne et al., 2000; Holloway, 2001; } \\
\text { Kennerley and Neely, 2002; Neely et al., 2000; } \\
\text { Nudurupati et al., 2011; Pawar and Driva, } \\
\text { 1999) }\end{array}$ & $\begin{array}{l}\text { Resistance to change, conservative attitudes, } \\
\text { general unwillingness, negative connotation } \\
\text { of control lead to impediments for an } \\
\text { effective implementation and adaption. }\end{array}$ & $\begin{array}{l}\text { Communication, both top-down and bottom } \\
\text { up is important when enforce changes } \\
\text { Literature on change- and culture } \\
\text { management are at hand. }\end{array}$ \\
\hline Ma11 & $\begin{array}{l}\text { Lack of reactive/ proactive actions } \\
\text { (Andrew et al., 2008; Brouthers, 1998; } \\
\text { Garengo et al., 2005; Kellen, 2003; Kennerley } \\
\text { and Neely, 2002; Nudurupati et al., 2011; } \\
\text { Pawar and Driva, 1999; Scozzi et al., 2005; } \\
\text { Smith and Goddard, 2002) }\end{array}$ & $\begin{array}{l}\text { Not acting reactively or proactively upon the } \\
\text { call of the output of an effective PMS } \\
\text { outstrips the purpose of the system as a } \\
\text { whole as it function is to aid management in } \\
\text { taking well informed decisions. }\end{array}$ & $\begin{array}{l}\text { Conceiving an open and well understood } \\
\text { system could make it easy for managers to } \\
\text { value the outcome and take it into account } \\
\text { Not discarding the information by means of } \\
\text { cultural changes could aid as well. }\end{array}$ \\
\hline
\end{tabular}




\begin{tabular}{|c|c|c|c|}
\hline Ma12 & $\begin{array}{l}\text { Large number of cross-disciplinary } \\
\text { stakeholders } \\
\text { (Cedergren et al., 2010; Cooper, 1985; } \\
\text { Franco-Santos et al., 2007; Griffin and Page, } \\
\text { 1993; Griffin and Page, 1996; Holloway, 2001; } \\
\text { Kennerley and Neely, 2002; Neely, 1999: } \\
\text { Neely, 2011; Roth and Senge, 1996; Scozzi et } \\
\text { al., 2005; Smith and Goddard, 2002) }\end{array}$ & $\begin{array}{l}\text { Variety in background of all stakeholders } \\
\text { leads to a complex composition of decision } \\
\text { makers, all defending their beliefs and } \\
\text { interests. Result: no generally accepted } \\
\text { approaches. }\end{array}$ & $\begin{array}{l}\text { An encompassing view, integrating various } \\
\text { perspectives should be done via a general } \\
\text { language understood by all; clear definitions, } \\
\text { logic priorities, defined strategy, } \\
\text { monetization. }\end{array}$ \\
\hline Ma13 & $\begin{array}{l}\text { Group decision making } \\
\text { (Lazzarotti et al., 2011; Malone et al., 2009; } \\
\text { Nunamaker et al., 1997; Schneiderman, 1999; } \\
\text { Turban et al., 2011) }\end{array}$ & $\begin{array}{l}\text { Metrics and results get negotiated and voted } \\
\text { upon, instead of analyzing data and } \\
\text { requirements. Subjective limitations (biases, } \\
\text { limited knowledge...) and time constraints } \\
\text { foster this practice. }\end{array}$ & $\begin{array}{l}\text { Tackling the subjective approach and setting } \\
\text { aside personal issues. MCDM/ MCMA, } \\
\text { computerized support systems, collective and } \\
\text { symbiotic intelligence. }\end{array}$ \\
\hline Ma14 & $\begin{array}{l}\text { Time pressure } \\
\text { (Chen et al., 2010; Kaplan and Norton, 2000; } \\
\text { Kellen, 2003; Lazzarotti et al., 2011; Neely, } \\
\text { 1998; Spitzer, 2007; Verworn and Herstatt, } \\
\text { 1999) }\end{array}$ & $\begin{array}{l}\text { Constructing and maintaining a personalized } \\
\text { PMS is a time consuming process. } \\
\text { Furthermore, external pressure from shorter } \\
\text { PLC and faster speed of innovation, forces the } \\
\text { PMS to respond quicker. }\end{array}$ & $\begin{array}{l}\text { A flexible but robust PMS that detects flaws } \\
\text { early on is the holy grail. Expenses should be } \\
\text { justified to tailor the model to the } \\
\text { organization's needs. }\end{array}$ \\
\hline
\end{tabular}

